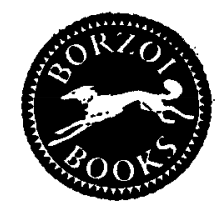

\title{
IN HONOR OF
}

\section{CHARLES AUSTIN}

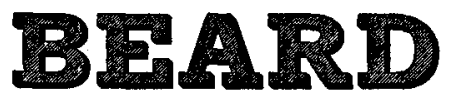

Alfred A. Knopf, Inc. announces the inauguration of the Charles Austin Beard Memorial Prize. This prize, intended to honor a great American, comprising five hundred dollars in cash and a contract for volume publication on terms set forth in the entry blank, will be offered in even years for a work in Political Science and in odd years for a work in American History. Any citizen of the United States not over forty years of age at the time of the closing date for entries will be eligible.

ManusCripts must deal with those subjects, and in a suitable manner, likely to appeal to the educated and mature American lay reader rather than to the specialist. Doctoral dissertations or works of a purely scholarly nature with a necessarily limited appeal are not eligible and will not be considered by the publisher.

ManusCRIPTS should be not shorter than 50,000 words nor longer than 150,000 words. Other things being equal, works of approximately 100,000 words in length will be favored.

MANUSCRIPTs must be submitted in clear typescript form complying in all respects with instructions set forth in the pamphlet which will be supplied candidates on application to the publisher who will also send a formal entry blank on request. Manuscripts must be in the publisher's hands complete and ready for the printer no later than July 31 st of each year.

\section{ALFRED $\cdot \mathrm{A} \cdot \mathrm{KNOPF}, \mathcal{P}_{\text {ublisher }}$}

501 Madison Avenue, New York 22

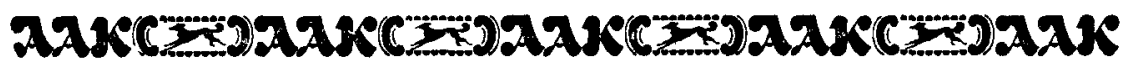




\section{THE REVIEW OF POLITICS}

Published by the University of Notre Dame

Vol. 14, No. 2

April, 1952

Includes

Robert Caponigri Don Luigi Sturzo

Joseph W. Evans The Personalism of Jacques Maritain

Frederick Barghoorn

Michael Pap

Stalinism and the Russian Cultural Heritage

Robert Ingrim

Soviet Difficulties in the Ukraine

Vincent De Santis

The Conversion to the Balance of Power

Republicans and the Democratic South, 18771892

Price, $\$ 4.00$ in the United States, Canada, and the Pan American Union $\$ 4.40$ in foreign countries. Single copy, $\$ 1.25$

THE REVIEW OF POLITICS

Box 4

Notre Dame, Indiana

\section{NEGOTIATING}

WITH THE

RUSSIANS

By

John R. Deane

JoHN N. HAZARD

Sidney S. Alderman

RAYMOND F. MIKESELL
George H. BlakesLeE

E. F. Penrose

MARK EThHIDGE
C. E. BLACK

Frederick Osborn

ERnest J. Simmons

Phulip E. Mosely

On

military assistance, lend-lease, the Nuremberg Trial Agreements, refugees and displaced persons, the Balkans, and atomic energy

\section{$\$ 3.50$ at your bookstore or}




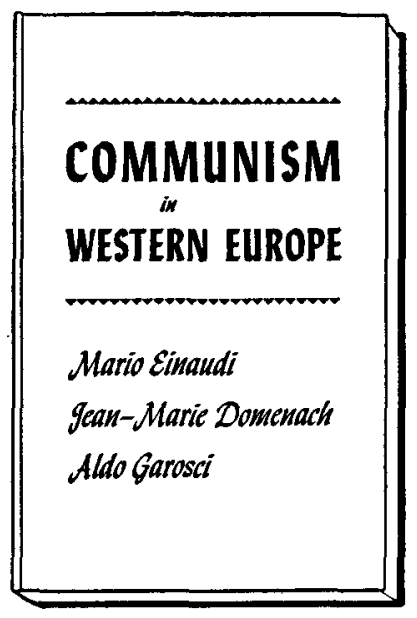

\section{\$300 Trade Ed.}

Paper covered text ed. $\$ 2.25$
"For anyone seriously interested in the histories of the French and Italian Communist parties, their leaders and their actual structure, this is a valuable and compact reference book."-The New York Times

THE AUTHORS know the situation in France and Italy from first hand experience. Mario Einaudi, Italian by birth, is now Professor of Government in Cornell University. JeanMarie Domenach, French journalist, is editor of Esprit; Aldo Garosci is an Italian political scientist. 248 pages.

\section{CORNELL UNIVERSITY PRESS, ITHACA, N.Y.}

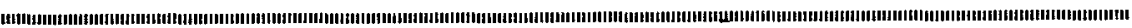

\section{International Political Science Abstracts Documentation Politique Internationale}

Published quarterly by the International Political Science Association and the International Studies Conference with the assistance of UNESCO and of the Co-ordinating Committee on Documentation in the Social Sciences.

editorial office: 27 , Rue Saint-Guillaume, Paris viI ${ }^{\circ}$ Provides abstracts (of roo-200 words) of all the articles in ten major Political Science Reviews and of articles concerning Political Science and International Relations published in more than 70 other journals throughout the world. Articles published in English are abstracted in French; all other articles are abstracted in English.

ANNUAL SUBSCRIPTIONS: $27 / 6 \mathrm{~d}$. Or $\$ 4$ or $1,600 \mathrm{frs}$. PER ISSUE: $7 /$ - or $\$ 1.00$ or 400 frs.

Vol. I, Nos. I-4 contains I,447 abstracts of articles published up to September I95I. Vol. II, No. I (to be published in March 1952) will contain articles published October-December 1951.

Basil Blackwell, Broad Street, oxford

Presses Universitaires de France, I, Place Paul Painlevé, Paris v ${ }^{\circ}$ 


\section{THE ROAD \\ TO PEARL HARBOR}

BY HERBERT FEIS

The coming of the war between the United States and Japan meticulously reported in a brilliant work of diplomatic history.

"Such a complete, scholarly, and balanced account of the events that it may be regarded as the final word."N.Y. Times.

"Because of this breadth and thoroughness of treatment, Mr. Feis's book will undoubtedly be without a peer for some time to come."-Far Eastern Quarterly.

"A scholar of recognized stature in the fields of economics and statecraft has here provided the first reasonably complete history of the origins of our war with Japan. ... The closely detailed narrative which he has woven will stand for a long time, I imagine, as definitive within its chosen area."-Walter Millis in N.Y. Herald Tribune.

"The primary task of the historian is to establish the facts' and Herbert Feis has admirably performed this task for the complicated and wearisome story of JapaneseAmerican relations, 1939-1941."-Political Science Quarterly.

“A remarkably clear and complete job of mapping for us every twist and turn of the road. . . . In time new materials may come to light, but there is little probability that they will alter the story appreciably."-American Historical Review.

368 pages.

$\$ 5.00$

PRINCETON UNIVERSITY PRESS 